\title{
The ever-muddled Canadian waters and elective ventilation
}

I t's not practical and it might be illegal but it may be desirable. It's safe to say there's a quintessentially Canadian divergence of views when it comes to elective ventilation but it was ever thus when it comes to matters of organ transplantation policy.

Little surprise then that the notion of improving organ donation rates by allowing people with severe brain injuries and hopeless prognoses to be placed on ventilators until they suffer brain death isn't on the Canadian table.

The topic hasn't been broached and the time hasn't come to even contemplate such a proposition, argues Dr. Sam Shemie, a physician in the Division of Pediatric Critical Care at Montreal Children's Hospital in Quebec and medical director for organs and tissues donation at Canadian Blood Services.

Although Canadian organ donation rates are "mediocre at best," far more rudimentary approaches to resolving the shortfall must be undertaken before even contemplating such "ethically controversial and difficult issues," Shemie says. "I think that we have to establish a national system or an inter-provincial system that is funded, that measures performance, that identifies where gaps in performance are, and really address the basics before we do anything that is much more controversial to the professionals and the public such as elective ventilation or such as something as simple as presumed consent."

Few would argue with the proposition that Canada's organ donation system is fractured, if not feeble (www .cmaj.ca/lookup/doi/10.1503/cmaj.0612 56). And despite four years of wrangling with provincial governments and transplant programs to create some form of national agency or mechanism for allocating donated organs for transplantation and improving organ donation rates, a recent strategic plan to create an "integrated inter-provincial organ donation and transplantation system"

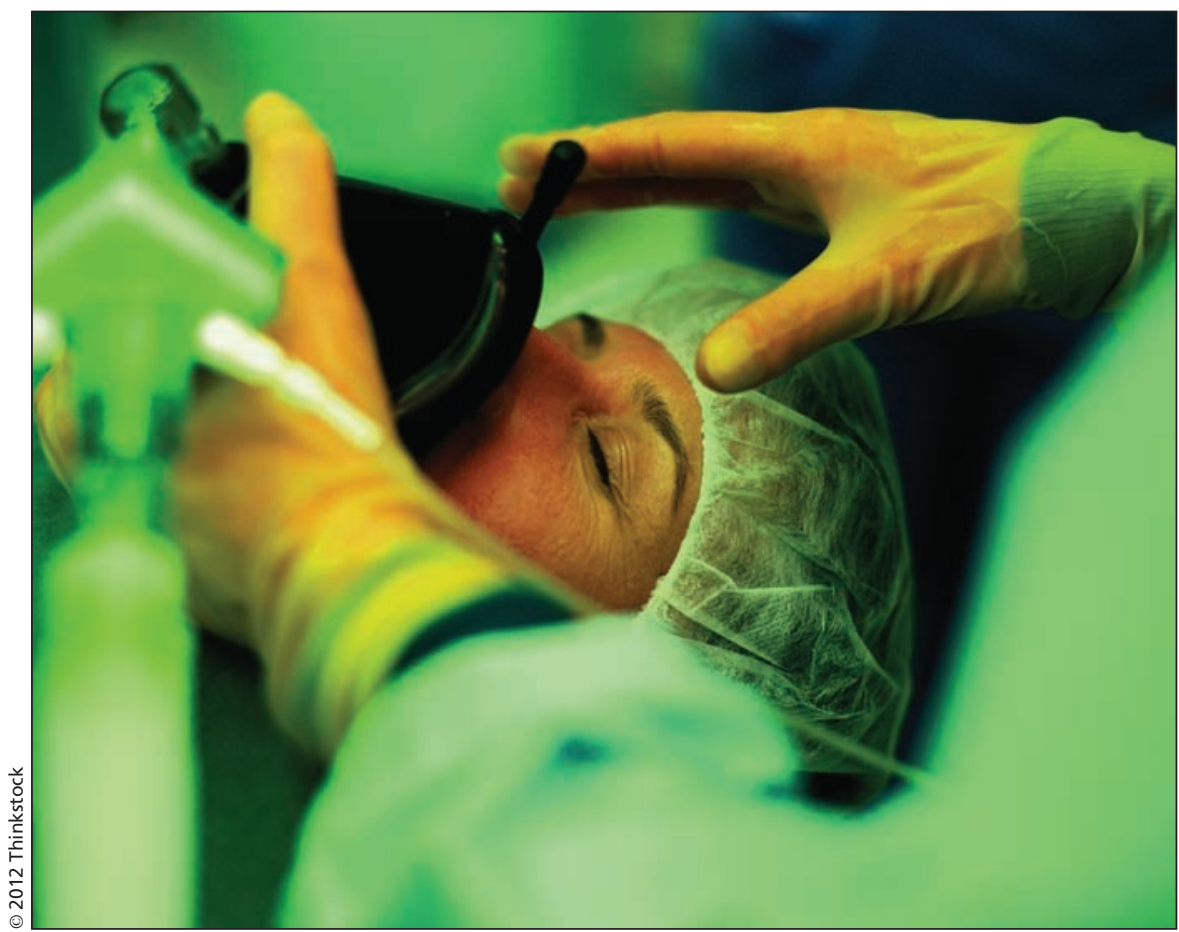

Even if elective ventilation prior to organ donation were to be allowed with consent, it might not be legal in all provinces and territories, according to one study.

doesn't even begin to address tactics, such as presumed consent or elective ventilation, that might be used to promote more organ donations (www.cmaj .ca/lookup/doi/10.1503/cmaj.109-4239).

But at least one national body would like to see discussion on the notion of elective ventilation.

"When an individual makes the choice of becoming an organ donor, I believe they expect the best care of their organs to insure successful transplants," James Breckenridge, president and CEO of the Canadian Transplant Society, writes in an email. "Can this procedure be considered standard practice or should it be addressed as a separate issue?"

"Perhaps this question and other controversial issues can be added to the person's organ donor registration form as technology and procedures change," Breckenridge adds. That would allow "complete understanding of the wishes of the donor, as well as peace of mind for the family," while reducing the "emotional impact of this and any other procedure."

But even if elective ventilation were to be allowed with such consent, it might not be legal in all provinces and territories, according to a study of "pre-mortem transplantation optimizing interventions" in Canada (Can J Anaesth 2008;55:458-69). Its authors came to the "unsettling conclusion" that it would probably be illegal.

While a competent patient might agree to a procedure intended to increase the likelihood of organ donation, that definitely wouldn't be the case for elective ventilation of incompetent patients, the study argued. And even for those who might be willing to give specific advanced consent, there is no mechanism within existing provincial tissue and organ donation regimes to allow for such consent, or to allow next of kin to provide it. 
The legalities would be even trickier because of the risk that such a patient might survive indefinitely in a persistent vegetative state, the study added. Moreover, while it might be possible that a case could be made for elective ventilation under some provincial consent and advance directives legislation, the lack of clear statutory provisions regarding consent to premortem interventions would probably put physicians at risk of being charged with offenses such as assault, battery and acceleration of death, the study adds, while urging legislatures to clarify their stances. Michael Monette, CMAJ

CMAJ 2012. DOI:10.1503/cmaj.109-4260
Editor's note: Second of a three-part series.

Part 1: British docs urge elective ventilation

(www.cmaj.ca/lookup/doi/10.1503/cmaj .109-4259).

Next: The ethics of elective ventilation 